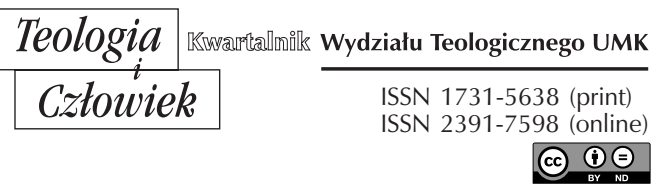

44(2018)4, ss. 143-162

MICHAEL ABDALLA

WYDZIAŁ NEOFILOLOGII UNIWERSYTETU ADAMA MICKIEWICZA W POZNANIU

MASATUR2@GMAIL.COM

ORCID 0000-0002-0933-3755

\title{
ANTIOCHIA I ALEKSANDRIA. Z DZIEJÓW RELACJI APOSTOLSKICH KOŚCIOŁÓW SYRO-MEZOPOTAMSKIEGO I KOPTYJSKIEGO
}

DOI: http://dx.doi.org/10.12775/TiCz.2018.043

\begin{abstract}
Streszczenie. W artykule przedstawiono ogólny zarys kontaktów między Antiochią i Aleksandrią, czyli między chrześcijanami Syro-Mezopotamii i Egiptu. Pominięto krótkie okresy, w których trony obu patriarchatów zajmowali arianie. Nie uwzględniono też powstałych po Soborze Chalcedońskim paralelnych patriarchatów procesarskich, czyli „melkickich” oraz stopniowo wyodrębnionych w wiekach XV-XVII zarówno Kościoła maronickiego (z macierzystego Kościoła Antiochii), jak i Kościołów unickich (z obu Kościołów Antiochii i Aleksandrii). Zakres tych relacji obejmował wymianę patriarchów i trwające do dziś zgodne stanowiska w kwestiach dogmatów wiary, a także udzielanie sobie nawzajem wsparcia i schronienia w czasach prześladowań, szczególnie po Soborze Chalcedońskim i wreszcie wciąż widoczne wspólne elementy w liturgii i praktykach religijnych.
\end{abstract}

Słowa kluczowe: Asyryjczycy; Koptowie; chrześcijaństwo; Egipt; Syria.

Abstract. Antioch and Alexandria: On the History of Syro-Mesopotamian and Coptic Apostolic Churches Relations. The paper briefly describes relations between Antioch and Alexandria, i.e. between Syro-Mesopotamian and Coptic Christians. Short periods when Arians held power in both patriarchates are omitted, as well as pro-imperial patriarchates established after the Council of Chalcedon, known as Melkites. Also the 
Maronite Church, which was gradually established in $15^{\text {th }}$ century from Antiochian Church, together with Uniate Churches (from both Alexandrian and Antiochian roots, starting from $16^{\text {th }}$ century) are omitted. The scope of these relations included exchanges of patriarchs; lasting to this very day common stance on dogmas; commonalities in liturgy and religious practices (which also last to this day). Both patriarchates offered support and asylum to each other in times of persecution, especially after the Council of Chalcedon.

Key words: Assyrians; Copts; Christianity; Egypt; Syria.

\section{WPROWADZENIE}

Spośród pięciu historycznych stolic zjednoczonego kiedyś świata chrześcijańskiego, tj. Jerozolima, Antiochia, Aleksandria, Rzym i Konstantynopol, obecnie tylko Rzym znajduje się w kraju o przeważającej ludności chrześcijańskiej. Antiochia i Aleksandria już w siódmym wieku zostały opanowane przez muzułmańskie hordy z Półwyspu Arabskiego, zaś Konstantynopol, przez wieki skutecznie odpierający kolejne próby jego zdobycia, niestety, mocno osłabiony w wyniku czwartej krucjaty, padł w piętnastym wieku pod ciosami Turków spod znaku półksiężyca. Jerozolima natomiast po ponad tysiącletnim muzułmańskim władaniu powróciła w połowie XX wieku do swoich prawowitych gospodarzy. Nie sposób też nie przypomnieć, że Antiochia, Aleksandria i Konstantynopol są wiekopomnym dziełem europejskich wielkich mężów, aczkolwiek, zdaje się, Europa o nich zapomniała.

Za założyciela Kościoła w egipskiej Aleksandrii uważa się Marka (Marqos) ewangelistę, a w syryjskiej Antiochii - apostoła Piotra (Fețrus, Buṭrus) $)^{1}$. Można sądzić, że w ich czasach podróżowanie w obrębie Imperium Romanum odbywało się bez przeszkód. Świadczy o tym wystąpienie cyrenejczyków² ${ }^{2}$ aleksandryjczyków do rozprawy ze św. Szczepanem

${ }^{1}$ Na podstawie prac pierwszych kronikarzy chrześcijańskich i treści listów niektórych papieży Rzymu, A. Rustum, Kanīsat madīnat allāh anțākiā al-'uzmā, Bejrut 1988, t. 1, s. 19-21, przypomina, że założycielem Kościoła w Antiochii i pierwszym jej patriarchą (lata 34-41) był św. Piotr. Obecnie urzędujący patriarcha Ignnāțiyyos Afrem II Karīm jest 123. patriarchą Syryjskiego Kościoła Ortodoksyjnego Antiochii (SKOA) po św. Piotrze, a Tawadros II - 118. papieżem aleksandryjskim po św. Marku.

2 Pochodzący z Cyrenajki (Libia wschodnia). Nazwę zawdzięcza założonemu 
w Jerozolimie (Dz 9,6), a także podróże Orygenesa $(† 234)$ do Syrii, Arabii, Grecji i Rzymu. Podróżowanie sprzyjało wymianie intelektualnej; już w pierwszych wiekach chrześcijaństwa przełożono na język syro-mezopotamski prace egipskich pisarzy, w tym żywot św. Antoniego ${ }^{3}$, a słynną

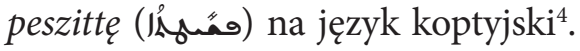

\section{MONASTYCYZM U ASYRYJCZYKÓW I KOPTÓW}

Analizując źródła syro-mezopotamskie znany syrolog A. Vööbus sformułował tezę, iż pierwsze oznaki ascetyzmu pojawiły się w okolicy miasta Nisibis ${ }^{5}$, a wzorce monastycyzmu zostały przeniesione z Mezopotamii do Egiptu i Grecji ${ }^{6}$. Już w III wieku góry Asyrii zaroiły się setkami pustelni, a pustelnicy często przewyższali najsurow-

przez Greków w r. 631 p.n.e. miastu Cyrena. Po arabskim, a następnie tureckim panowaniu (644-1517-1911) Cyrenajkę wyzwolili Włosi i stała się ich kolonią do r. 1934. Z niej wywodził się zarówno Szymon cyrenejczyk, który pomógł Chrystusowi nieść krzyż (Mt 27,32; Mk 15,21 i Łk 23,26), jak i rodzice Marka Ewangelisty. Postanowieniem Ojców Soboru Nicejskiego Cyrenajka podlegała Aleksandrii, podobnie jak Indie uznawano za teren pod jurysdykcją Antiochii.

3 Zob. Św. Atanazy Aleksandryjski, Żywot świętego Antoniego. Św. Antoni Pustelnik. Pisma, Z. Brzozowska i inni (tłum.), E. Wipszycka (wstęp i komentarz), Warszawa 1987, s. 52-53.

${ }^{4}$ R. Duval, Tārīh al-adab as-syriānī (arabskie tłumaczenie z francuskiego L. Qașșāb), Bagdad 1992, s. 166-167. I. Armala, As-Syriān fī al-quțr al-mișrī, Bejrut

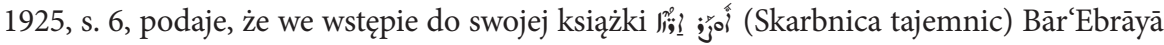
$(\dagger 1286)$ donosi, że Orygenes widział egzemplarz peszitty u egipskiej wdowy. O tym jednak nie wspomina Euzebiusz z Cezarei w Historii Kościoła. O męczennikach Palestyńskich, Poznań 1924, ani A. S. Atiya w Historii Kościołów Wschodnich, Warszawa 1978. Ūṣār rōzē jest komentarzem do ksiąg Starego i Nowego Testamentu.

${ }^{5}$ Starożytne miasto asyryjskie Șōbā, dziś Nusaybin (południowo-wschodnia Turcja), w latach I wojny światowej opanowali je Kurdowie, a rdzenni mieszkańcy (Asyryjczycy i Żydzi) przenieśli się do nowo wybudowanego miasta Kamiszli (Zālīn), po drugiej stronie dzisiejszej granicy syryjsko-tureckiej.

${ }^{6}$ A. Vööbus, History of Asceticism in the Syrian Orient I, Louvain 1958, (CSCO 184), Tenże, The Contribution of Ancient Syrian Christianity to the West European Culture, "Journal of Assyrian Academic Society", 1 (1988), s. 8-14. Tradycja przypisuje początek ruchu monastycznego w Mezopotamii i Persji Mār Auginowi (św. Eugeniusz) z Klizmy (Suez w Egipcie), co miało nastąpić w IV wieku. 
szy ascetyzm wczesnych egipskich mnichów i słynnych ojców pustyni egipskiej.

Monastycyzm tak rozwinął się w Egipcie, że św. Jan Złotousty (†407) miał go opisać go w te słowa: „Gdybyś w naszych dniach udał się do Egiptu, zauważyłbyś, że dzięki podobnym do kwiatów pustelnikom i wielości zgromadzeń ascetów ten kraj wygląda niczym ogród, który góruje nad wszelkimi innymi ogrodami. Ich blask zasłania nawet blask gwiazd na niebie. Znawca starych zwyczajów Egipcjan, zobaczywszy gruntowną zmianę ich sposobu życia, uwierzy w moc Jezusa Chrystusa"7.

Tak utrwalony obraz, z pewnością znany w tłumaczeniu na język syro-mezopotamski, przyciągał do Egiptu gorliwych chrześcijan Syro-Mezopotamii. Wybierali się do Shee-Hyt ${ }^{8}$, aby nie tylko spotkać i podziwiać owych tysięcy mocarzy wiary, ale do nich się dołączyć.

Niewątpliwie, dzięki szerokiemu zasięgowi geograficznemu swojego języka Asyryjczycy przyczynili się do upowszechnienia wiedzy o egipskiej formie monastycyzmu, szczególnie w Syrii, Mezopotamii i Persji, a w okresie chlubnych misji także na Kaukazie i w Azji Środkowej. Wskazuje na to tłumaczona na syro-mezopotamski kronika ojców pustyni Ogród mnichów, autorstwa biskupa Palladiusza ${ }^{10}$. Tłumaczenie za namową asyryjskiego katolikosa Giwargisa (†680) wykonał 'Nān-Yěšŭ ${ }^{c}$. Tak oni

7 Cytat pochodzi od I. Armala, As-Syriān, s. 6. Według A. S. Atiya, Historia Kościołów, s. 57, Jan Chryzostom przebywał w egipskim klasztorze św. Pachomiusza w Tebaidzie w latach 373-381.

8 Wādī an-Națūn (arab.), Sketis, Skete (gr.) - kraina pomiędzy Aleksandrią a Kairem, z klasztorami, z których najstarszy datuje się na IV wiek.

9 M. Kāmil, M. H. al-Bakrī, Z. M. Rušdī, Tārīh al-adab as-syriānī min našatihi ilā al'aṣr al-ḥādir, Kair 1987, s. 163-164.

${ }^{10}$ W roku 2006 Kościół koptyjski wydał poszerzoną wersję Ogrodu mnichów, liczącą 1867 stron. Spośród prac wydanych w języku polskim, z cząstkowym opisem żywota i apoftegmatów ojców pustyni egipskiej, na uwagę zasługuje teologiczna analiza eremityzmu i anachoretyzmu M. Schneidera, Ze źródeł pustyni. Znaczenie Ojców Pustyni dla współczesnej duchowości, Kraków 1994. O tłumaczeniach ksiąg ascetycznych na język syro-mezopotamski i ich upowszechnieniu od IV wieku pisze Iġnāṭiyyos Afrem I Barșaum, Al-Lu'lu' al-mantūur fì tārīh al-'ulūm wa-l-ādāb as-syriāniyya, Bagdad 1976, wyd. 3, s. 120-126; w niemieckim tłumaczeniu przez G. Toro, A. Gorgis: Mor Ignatios Aphrem I. Barșaum, Geschichte der syrischen Wissenschaften und Litetatur, Wiesbaden 2012, s. 105-109.

11 Było to nowe tłumaczenie na bazie przekładów z IV-V wieku, wzbogacone 
postąpili, pomimo że należeli do Kościoła nazwanego „nestoriańskim”, z którym Kościół Aleksandryjski, nazwany „monofizyckim”, formalnie nie miał dobrych relacji. Pamiętajmy też, że liczni w obu Kościołach asceci, podobnie jak messalianie ${ }^{12}$, nie byli podporządkowani administracji kościelnej. W Ogrodzie mnichów czytamy, że do Egiptu przybyła grupa pobożnych Asyryjczyków, aby otrzymać od nich błogosławieństwo. Wśród nich miał być św. Efrem, który pragnął spotkać Anbę Bī̌̄ōy, a po tygodniowym pobycie w klasztorze wędrował po Sketis i działał pośród Arian, po czym powrócił do swojej ojczyzny, Edessy"13.

Do Egiptu udał się Milles, biskup miasta Šūšān ${ }^{14}$, późniejszy męczennik ${ }^{15}$. Po pielgrzymce do Jerozolimy dopłynął do Aleksandrii i odwiedził uczniów św. Antoniego, a po dwóch latach, drogą przez Nisibis, gdzie miał pomóc św. Jakubowi (†338) w budowie kościoła ${ }^{16}$,

o ponad tysiąc apoftegmatów i mowy ojców Kościoła, w tym Jana Chryzostoma. To imponujące dzieło natchnęło mnichów syro-mezopotamskich do napisania pieśni i hymnów o ojcach koptyjskich, włączonych do liturgii. O twórczości tłumacza i bibliografii do niej oraz o samym przekładzie zob. A. Abūnā, Adab al-lug̉a al-ārāmiyya, Bejrut 1996, wyd. 2, s. 262-265.

12 Od wyrazu مكَحْ (mșaliānāa $)$ - modlący się.

${ }^{13}$ Obie społeczności wierzą, że św. Efrem był w Egipcie i jest to wzmiankowane w wielu pismach. W klasztorze „Dayr as-Syriān” (Klasztor Asyryjczyków) w Wādī an-Națūn stoi drzewo podobne do tamaryndowca indyjskiego, nazywane drzewem św. Efrema. Z jego kwiatów i owoców przygotowuje się napar dla pielgrzymów. Wiemy, że św. Efrem opuścił Nisibis w roku 363, a zmarł w Edessie 10 lat później. A. Scher, Tārīh Kaldō wa Ātūr, Bejrut 1913, t. 2, s. 48-50, przytacza argumenty obalające pogląd o pobycie św. Efrem w Egipcie. Takie stanowisko zajmuje również R. Duval, Tārīh al$-a d a b$, s. 354.

14 Šūšān (po asyryjsku i hebrajsku), dawna Suza w Persji. Warto odnotować, że obchodzone w marcu w Izraelu święto Szuszan Purim ma przypominać ocalenie Żydów w starożytnej Persji. W ich trakcie często prezentuje się operę Nabucco Giuseppe Verdiego, nawiązującej do wydarzeń będących początkiem „niewoli babilońskiej”.

${ }_{15}$ W okresie trwających 40 lat (339-379) prześladowań chrześcijan za Szapura II; według H. Sozomena, Historia Kościoła, Warszawa 1989, s. 105-106, miało zginąć 16 tysięcy „znanych z imienia”. Asyryjskie źródła mówią o 290 tysiącach, arabskie zaś o 200 tysiącach. Opis żywota i męczeństwa Millesa (13 XI 341 r.) podają A. Abūnā, Šuhadā' al-Mašriq, Bagdad 1985, t. 1, s. 158-163; tenże, Adab al-luġa, s. 63, 68.

${ }^{16}$ Budynek kościelny zachował się do dziś jako jedyny ślad przeszłości chrześcijańskiego kiedyś miasta, w którym św. Jakub i jego uczeń św. Efrem założyli akademię i w niej działali, zob. N. Pigulewska, Kultura Syryjska we wczesnym średniowieczu, Warszawa 1989. 
i dalej przez Adiabene (północny Irak), powrócił do swojej siedziby w Ruzaiq ${ }^{17}$.

W Egipcie przebywał także św. Mīhāā, który 15 lat służył w małej celi, po czym drogą przez Tur Synaj, Jerozolimę i Mardin powrócił do Qaraqō̌s (Bağdēdā, wioska w Dolinie Niniwy), gdzie po jej wschodniej stronie zbudowano klasztor utrwalający jego imię ${ }^{18}$.

Prawie zawsze droga do Egiptu lub powrotna z Egiptu wiodła przez Jerozolimę, do której pielgrzymowali mnisi ze Wschodu. Tą trasą do Sketis udał się „nestorianin” Abraham Wielki (†586) z Kaškar ${ }^{19}$, biskup miasta Al-Hīra (na południu Iraku). W Egipcie spędził wiele lat wśród koptyjskich mnichów i zapoznał się z regułą św. Makarego Wielkiego, współczesnego św. Pachomiuszowi. W drodze powrotnej odwiedził pustelnie na Synaju, zatrzymał się w klasztorze Przemienienia Pańskiego (później Św. Katarzyny) ${ }^{20}$, a po pielgrzymce do Grobu Pańskiego doszedł do góry Izlōón w Ṭūr 'Abdīnie, gdzie zbudował klasztor dla setek mnichów ${ }^{22}$. Jest autorem reguły monastycznej składającej się z 571 przepisów,

${ }^{17}$ Inne pisownie Raziq, Bēt Razqāyē, w okręgu ar-Rayy, $45 \mathrm{~km}$ na południowy zachód od Teheranu.

$18 \mathrm{O}$ nim w I. Armala, As-Syriān, s. 7; A. Abūnā, Adab al-luğa, s. 153.

${ }_{19}$ Miasto oddalone o $180 \mathrm{~km}$ na południowy wschód od Bagdadu, w pobliżu dzisiejszego Al-Kut. Zbudowane w połowie III w. przez Szapura I jako miejsce dla jeńców rzymskich, do XII w. było znaczącym ośrodkiem chrześcijańskim podległym patriarsze w Seleucji-Ktezyfonie. A. Harrak (tłumaczenie i wprowadzenie), The Acts of Mār Mārì the Apostle, Atlanta 2005, s. 69 i J. Daniélu, H. I. Marrou, Historia Kościoła, Warszawa 1984, t. 1, s. 280, określają Abrahama terminem znakomitego organizatora monastycyzmu. Zob. też: Ch. Baumer, The Church of the East. An Illustrated History of Assyrian Christianity, London-New York 2008, s. 22, 88, 128.

${ }^{20}$ E. L. Butcher, History of the Coptic Nation and Orthodox Church, London 1897 (w arabskim tłumaczeniu dokonanym przez I. Tadarusa: Tārīh al-umma al-qibțiyya wa kanīsatihā, Kair 1900, t. 1, s. 165-180), udowadnia, że św. Katarzyna nie bywała w Egipcie i nie należy do tego kręgu; nazwę nadano po wyprawach krzyżowych i zachowano ze względu na turystów zachodnich. Faktyczną patronką jest Koptyjka Damiana, męczennica w czasach prześladowań Dioklecjana.

${ }^{21}$ Płaskowyż Izlō (biblijny Uzzal, Ez 27, 19), zob. H. Hollerweger, Turabdin - Living Cultural Heritage, Linz 1999, s. 20 (wydanie albumowe). W komentarzach do Biblii Tysiąclecia podano, że pod nazwą Uzzal kryją się „arabskie szczepy”, mimo że w VI w. p.n.e. Arabów w tym regionie jeszcze nie było!

${ }^{22}$ Obecnie w Țūr 'Abdīnie czynne są dwa klasztory pod wezwaniem Mōr Abrōhom: w Midyacie i w Marbōbō, zob. H. Hollerweger, Turabdin, s. 108-111, 304. 
wzorowanej na regule św. Makarego Wielkiego. Jest w niej mowa, że mnisi „nestoriańscy” mają obowiązek golenia włosów w kształcie korony, aby odróżnić się od mnichów „jakobickich”. Nie jest wykluczone, że ta

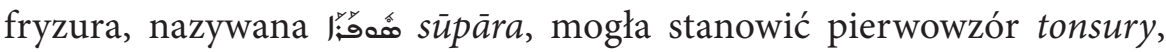
charakteryzującej kilka zakonów powstałych w Kościele Rzymskim.

Zachował się epizod z życia Mārān Zhăāa († ok. 750), biskupa Ḥdịty ${ }^{24}$, opisany przez Tūmā d-Margā (IX w.), „nestorianina”:

Mārān Zhāā wybrał się na modlitwę do góry w pobliżu wsi Zaynō. U podnóża góry spotkał starca pasącego wielbłądy i słyszał jak nuci syro-me-

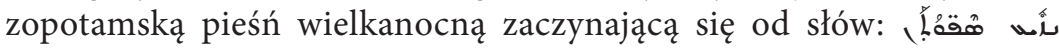
(chodźmy, wszystkie ludy, poruszyć nasze wargi!). Wzruszony biskup zatrzymał się, pozdrowił pasterza i prosił, aby zdradził swoją narodowość. Starzec odpowiedział po arabsku: „Mnichu, czego chcesz ode mnie? Idź w pokoju swoją drogą!". Biskup jednak nalegał, aby mu wyjaśnił skąd zna arabski. Starzec odpowiedział: „Wiedz, mój Panie, 40 lat temu moi rodacy w Egipcie wybrali mnie na swojego biskupa. Kiedy pewnego dnia udałem się z grupą wiernych na pustynię na medytację, zaatakowali nas Beduini. Moi wierni uciekli, mnie zaś zatrzymali, zabrali do swoich namiotów i kazali paść wielbłądy, i tym się zajmuję od 40 lat". Słysząc to, Mārān Zhāa ukląkł przed starcem, ucałował jego ręce, prosił o błogosławieństwo i pożegnał się. Wracając tą samą drogą po kilku dniach, wielbłądów nie spostrzegł, lecz zauważył, że pasterz leży sztywny. Namaścił go, pochował i skupiony w modlitwie spędził przy jego grobie cały dzień, po czym zabrał obie peleryny, które pasterz nosił, niczym relikwie, i wrócił do Hidìty ${ }^{25}$.

W Egipcie pochowany jest niejeden asyryjski duchowny. W klasztorze pod wezwaniem Marii Dziewicy w Wādī an-Naṭrūm znajduje się

${ }^{23}$ Biskup o takim samym imieniu rezydował w Adiabene (347-376). Swój żywot zakończył jako męczennik w czasie perskich prześladowań, zob. I. Armala, Tārīh al-kanīsa as-syriāniyya, Bejrut 1996, s. 81.

${ }^{24}$ Ḥìta - asyryjskie miasteczko nad wschodnim brzegiem Tygrysu, w pobliżu rzeki Wielkiego Zabu, w odróżnieniu od obecnego miasta zamieszkałego przez sunnitów w prowincji Al-Anbār nad Eufratem, $240 \mathrm{~km}$ na północny zachód od Bagdadu.

25 Thomas, Bishop of Margâ, The Book of Governors, E. A. W. Budge (ed.), edited from Syriac Manuscripts from the British Museum and other Libraries, London 1893, s. $273-281$. 
grób św. Mārūty (†420), biskupa Miparqat (Maiperqat, Mayyafāraqīn). Zapisał się on w historii jako reformator Kościoła w Persji i mediator między Teofilem, patriarchą Aleksandrii i św. Janem Chryzostomem ${ }^{26}$, a także między Persją i Bizancjum. Do jego zasług zalicza się zabranie do Miparkat doczesnych szczątków męczenników z Persji, które to miasto zaczęto odtąd nazywać Martyropolis. Jednak, kiedy i z jakiego powodu jego ciało znalazło się w Egipcie, o tym źródła milczą. Podczas pobytu Assemaniego $(\dagger 1768)$ w owym klasztorze w celu nabywania rękopisów syro-mezopotamskich i zabrania ich do Watykanu, mnisi mieli pokazać mu grób Mārūty i dzieła jego autorstwa, ale za żadne pieniądze nie chcieli ich sprzedać ${ }^{27}$. Assemani był Libańczykiem pracującym w założonym w r. 1584 w Rzymie Kolegium Maronickim i autorem wiekopomnego dzieła Bibliotheca Orientalis.

Nie sposób wymienić wszystkich duchownych Syrii i Mezopotamii, którzy za to, że odmówili przyjęcia postanowień Soboru Chalcedońskiego zostali $\mathrm{z}$ rozkazu cesarza Justyna I (518-527) skazani na wygnanie do odległych krain i jedynie dzięki wstawiennictwu cesarzowej Teodory ${ }^{28}$, żonie Justyniana I (527-565), pozwalano im udać się do Aleksandrii. Tak było z Mārą, biskupem Amidy (dzisiaj Diyarbakir w Turcji) i Izydorem, biskupem Qennešrére ${ }^{29}$. Po siedmiu latach wygnania w nabatejskiej

${ }^{26}$ Zob. H. Sozomen, Historia, s. 554; S. Scholastyk, Historia Kościoła, Warszawa 1986, s. 477, 486, 504-505.

27 J. Daniélu, H. I. Marrou, Historia Kościoła, s. 218-219. Masowe nabywanie rękopisów towarzyszyło akcjom prozelityzmu wśród chrześcijan Bliskiego Wschodu, rozpoczętym od XVI wieku na szeroką skalę przez Rzym. Przed Soborem Trydenckim wiele rękopisów zebranych z klasztorów przez „misjonarzy katolickich”, wspieranych przez turecką żandarmerię, spalono, np. w Libanie. Pisze o tym Ph. De Tarrazzi, Aşdaq mā kān 'an tārīh Lubnān wa şafḥa mun aḥbār as-syriān, Bejrut 1948, t. 1, s. 96-100. Tak też postępowano na Malabarze w Indiach, zob. S. Y. Tūmā, Tārīh al-kanisa as-syriāniyya al-hindiyya, Bejrut 1951, s. 418. Po Soborze Trydenckim z rękopisów wydrapywano wyrazy "Antiochia” i „patriarcha”, zapisując w to miejsce „Rzym” i „papież”. Takie egzemplarze widziałem w dziale rękopisów biblioteki uniwersyteckiej w Gotha w Niemczech.

${ }^{28}$ Niejeden autor podkreśla niegreckie pochodzenie zarówno św. Heleny, matki Konstantyna Wielkiego, jak i Teodory. Jedni piszą, że Teodora była Asyryjką i córką księdza z Mabug, inni twierdzą, że była Egipcjanką urodzoną w Aleksandrii i tym tłumaczą jej nieustanną troskę o „monofizytów”, co miało wywołać podwójną wobec niej niechęć dygnitarzy i pisarzy bizantyjskich, którzy przedstawili ją w złym świetle.

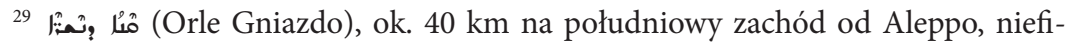


Petrze obaj znaleźli się w Stolicy Markowej, gdzie prowadzili ascetyczny tryb życia. Wykorzystując swoją wiedzę i przemyślenia teologiczne oraz doskonałą znajomość greki, Māra napisał m.in. komentarze do Nowego Testamentu. Zmarł w Aleksandrii w roku 52930.

\section{PO SOBORZE CHALCEDOŃSKIM}

Nieporozumienia między stolicami patriarszymi na Soborze Chalcedońskim, a wcześniej na Soborze Efeskim, stworzyły sytuację, która niejako zmusiła autochtonów terenów opanowanych przez Bizancjum: Ormian, Asyryjczyków, Koptów i Arabów, przez Konstantynopol i Rzym nazwanych „monofizytami”, do wzmocnienia relacji między sobą. Złożony z urzędu przez cesarza Justyna I i skazany na banicję w roku 519 patriarcha Antiochii Seweriyyos (Sewer) Wielki udał się do Egiptu i w obawie przed aresztowaniem przez bez mała 19 lat przenosił się z jednego klasztoru do drugiego, aż do swojej śmierci w Aleksandrii 8 lutego $538 \mathrm{r}^{31}$ Słowa jednej z syro-mezopotamskich pieśni kościelnych brzmią:

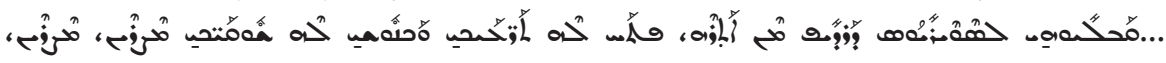
„Egipcie, Egipcie, powitaj Seweriyyosa wygnanego ze swojej ojczyzny, otwórz

gurujące na mapie dzisiejszej Syrii. Także w Turcji, ok. $20 \mathrm{~km}$ na północ od granicznego miasta syryjskiego Dżarabulus, znajdowała się miejscowość o nazwie Dayrō d-Qennešrē, dziś Birecik nad Eufratem.

${ }^{30}$ Więcej informacji o nim można znaleźć w: R. Duval, Tārīh al-adab, s. 385; I. Armala, Tārīh al-kanīsa, s. 173-174; A. Abūnā, Adab al-lugia, s. 212-213; Texts and Translations of the Chronicle of Michael The Great, G. A. Kiraz (ed.), vol. 1, The EdessaAleppo Syriac Codex of the Chronicle of Michael The Great, A Publication of St. George Parish and Edessian Community in Aleppo, Piscataway/NJ 2009, s. 268-270 [dalej: Codex...]. W arabskim tłumaczeniu tego samego rękopisu przez abpa Mosulu, G. S.. Šamūn, Tārīh Mār Mīhāìil as-syriānī al-kabìr, Aleppo 1996, t. 2, s. 52-54 [dalej: Kronika...]; w wydanym w Szwecji w jednym tomie (ss. 849) w syryjskim zapisie komputerowym, Ktōoō d-makțbōnūt zabnē 2006, s. 322 [dalej: Ktōobō...].

31 'A. Ğamāl ed-Dīn (red.), Tārīh Mișr min hilāl maḥțūṭat tārīh al-bațārika li-Sāwìros ibn al-Moqaffa', Kair 2006, t. 1, s. 396-407. Podobne okoliczności miały miejsce na przełomie XIX i XX wieku; ścigani przez Osmanów za działalność na rzecz wyzwolenia ziem „arabskich” chrześcijańscy intelektualiści Libanu, Syrii i Mezopotamii szukali schronienia w Egipcie. To oni założyli i wydawali dziennik „Al-Ahram”, który wychodzi do dziś. 
mu swoje bramy, sprzataj przed nim ulice..."32, a w modlitwie ku czci ojców Kościoła podczas mszy świętej jest on określany بَّ (Korona Asyryjczyków) ${ }^{33}$.

Po śmierci Sewera na biskupa Edessy konsekrowano Jakuba Baradeusza (Yáqūb Burdōōō, 542 r.). Źródła podają, że spośród całego dochalcedońskiego duchowieństwa antiocheńskiego był on podobno jednym z dwóch, których nie dosięgły prześladowania bizantyjskie. Konsekracji, przy zaangażowaniu Teodory i wsparciu Al-Ḥarit ibn Ğabla, króla arabskich Ghassanidów (Ghassanidzi należeli do SKOA), dokonał internowany w Konstantynopolu aleksandryjski papież Teodozjusz I. Niestrudzony J. Baradeusz wiele podróżował, wszędzie wyświęcając duchownych i wzmacniając prześladowanych, stąd też wzięła się pejoratywna nazwa „jakobici”, obejmująca niebizantyjskich i nienestoriańskich chrześcijan Bliskiego Wschodu, Armenii i Indii ${ }^{34}$. Zaproszony do Aleksandrii J. Baradeusz uczestniczył w konsekracji biskupa Pola (Pawła) Abisyńskiego na patriarchę $(† 581)$ dla antiocheńskich ,jakobitów” po czteroletnim wakacie. Kilka lat później Koptowie ujęci pobożnością i wiedzą przebywającego w Egipcie asyryjskiego biskupa Damiana, wybrali go na swojego patriarchę (†605). Słysząc o tym J. Baradeusz udał się z trójką biskupów do Aleksandrii, by złożyć mu hołd. Była to trzecia jego wizyta w Egipcie. Kiedy J. Baradeusz zmarł (†578), tenże patriarcha, nie mogąc uczestniczyć w ceremonii pogrzebowej, oddelegował dwóch egipskich biskupów z listem kondolencyjnym, w którym wymienia ogromne zasługi zmarłego i jego

32 Tekst syryjski z arabskim tłumaczeniem, zob. Ig̉nāțiyyos Yáqūb III, Naf̣̣ al-'abìr aw sìrat al-bațriark Mār Seweriyyos al-kabīr, Damaszek 1970, s. 115. Asyryjska nazwa Egiptu występuje w liczbie podwójnej (مَُّْْم: dwa Egipty, tj. Górny i Dolny). Formę liczby podwójnej w językach semickich wyjaśnia metropolita Damaszku: Q. Y. Dāwūd, Al-Lumá aš-šahiyya fì naḥu al-lug̉a as-syriāniyya, Mosul 1896, t. 1, s. 357-358. Jako wyodrębniona kategoria zachowała się w języku arabskim, Asyryjczycy zaś przestali jej używać.

${ }^{33}$ Pamięć o św. Sewerze jest w Kościele Koptyjskim obchodzona 4 razy w roku.

${ }^{34}$ W literaturze zachodniej nazwy „jakobici” i „monofizyci” występują zamiennie. Obie są obce społecznościom, do których się odnoszą i uważane za złośliwe. Prawdopodobnie nazwa „jakobici” została nadana w reakcji na nazwanie współziomków, zwolenników postanowień Soboru Chalcedońskiego, „melkitami” (tj. „procesarscy”). A ponieważ Konstantynopol i Rzym były do r. 1054 zjednoczone, te nazwy zdążyły utrwalić się w literaturze obu Kościołów. Taki pogląd wyraża m.in. M. Yūḥannā, Tārīh al-kanīsa al-qibțiyya [brak miejsca i daty wydania], s. 279-280. 
wysiłki o jedność Kościoła ${ }^{35}$. Syro-Mezopotamscy duchowni cieszyli się taką popularnością, że Nubijczycy i Etiopczycy spośród nich chcieli mieć biskupów. Tę misję precyzuje egipski historyk muzułmański Al-Maqrīzī:

Asyryjczycy byli liczni i widoczni w Egipcie. Z Egiptu oddelegowali do Etiopii księdza Juliana, który służył u papieża aleksandryjskiego Teodozjusza I. Przez dwa lata od godziny piętnastej do dwudziestej pierwszej Julian chrzcił ludzi wodą z cystern i przyłączył ich nie do patriarchatu antiocheńskiego, lecz do aleksandryjskiego i w ten sposób wzmocnił pomosty między nimi ${ }^{36}$.

Biblioteka Aleksandryjska, ze względu na posiadane zasoby najbardziej znana w czasach starożytnych, przyciągała poszukiwaczy wszelkiej wiedzy. W tamtym czasie nie było syro-mezopotamskiego pisarza, który by greki nie znał i w niej nie pisał swoje dzieła. Oto lista nazwisk, z konieczności ograniczona do kilku, którzy dzięki greckim dziełom aleksandryjskim, a także rodzimej twórczości we własnym języku, przyczynili się $\mathrm{w}$ większym lub mniejszym stopniu do rozwoju nauk humanistycznych na Bliskim Wschodzie:

Sṭefanos BārȘudaylō $(† 510)$ z Edessy. Po solidnej nauce w Egipcie wykładał grekę w Jerozolimie i w swoim rodzinnym mieście. Jest autorem mów i komentarzy, szczególnie do Psalmów, zachował się jego przekład z greki na syro-mezopotamski dzieła apokryficznego niejakiego Herotiusza, w którym Herotiusz występuje jako nauczyciel syryjskiego mnicha Pseudo-Dionizego Areopagity. Sțefanos słynął z poglądu o niewieczności mąk piekielnych, za co znalazł się w ogniu krytyki zarówno św. Jakuba z Sarug (†521), jak i Filoksenosa z Mabug $(† 523)^{37}$.

35 Treść tego listu mająca formę elegii zamieścił w swojej kronice Mār Mihōoyel Rābō, Codex, s. 410-411; Kronika, s. 225-228; Kțōbō, s. 432-434 (prawa kolumna).

36 T. D. Al-Maqrīzī (XV w.), Al-Mawā'īz wa-l-ítibār fì dikr al-hițaț wa-l-ātāar, M. Zenhum, M. aš-Šarkāwī (red.), Kair 1998, t. 2, s. 493; Z. Riāḍ, Kanīsat al-Iskandariyya fì Ifrīqia, Kair 1962, s. 159-165; A. S. Atiya, Historia Kościołów, s. 389; Ph. De Tarrazzi, 'Așr as-syriān ad-dahabi, Aleppo 1979, s. 19.

37 R. Duval, Tārīh al-adab, s. 382-383; A. Abūnā, Adab al-lugia, s. 188-189; Ig̉nāțiyyos Afrem I Barșaum, Al-Lu'lu’ al-mantūur, s. 216-217; Geschichte, s. 191; M. Kāmil, M. H. al-Bakrī, Z. M. Rušdī, Tārīh al-adab, s. 190-192. 
Mało szczęścia mieli dwaj uczeni „nestoriańscy”: Tūmā (Tomasz) Edeski i katolikos Mār Ābā Wielki (540-552). Obaj wyruszyli do Egiptu i z powodzeniem szerzyli chrześcijaństwo w środowisku pogan, ale z powodu działalności także wśród „monofizytów” zostali wydaleni przez Koptów $^{38}$.

W latach 485-487 w Aleksandrii studiował grekę Zharyō (Zachariasz) Retor († po 536), asyryjski biskup urzędujący po roku 527 na greckiej wyspie Lesbos ze stolicą w Mitylenie ${ }^{39}$. Urodzony na wsi w pobliżu Gazy był szkolnym rówieśnikiem Sewera Wielkiego i pod wpływem jego nauki przyjął chrzest w Trypolisie w Libanie. Interesował się naukami filologicznymi, wykładał prawo i filozofię w Bejrucie. Jest autorem pierwszej biografii swojego mistrza Sewera i jednej z pierwszych kronik obejmującej lata 450-491, z której czerpali późniejsi kronikarze syro-mezopotamscy, w tym Jan z Efezu. Większość swoich dzieł napisał po grecku i jeszcze za życia tłumaczono je na syro-mezopotamski ${ }^{40}$.

Patriarcha Ig̉nāṭiyyos Afrem I Barșaum (†1957) badając treść kolofonów w rękopisach syro-mezopotamskich przechowanych szczególnie w Watykanie i Londynie, podaje, że w jednym z londyńskich jest napisane, iż „Faulos (Paweł), monofizycki biskup Tella (Tellu) ${ }^{41}$ (†617) chroniąc się w Egipcie przełożył z greckiego na syro-mezopotamski księgi biblijne oraz zbiór 150 kazań wygłoszonych przez Sewera Wielkiego”. Dokładniej-

${ }^{38}$ N. Pigulewska, Kultura Syryjska, s. 164 i nast. O tym wybitnym katolikosie, podobnym do apostołów, któremu poświęcono wiele publikacji w różnych językach, brak wzmianki w pierwszym tomie Historii Kościoła autorstwa J. Daniélu i H. I. Marrou, obejmującym lata „od początków do roku 600”. Jednak „nestorianie” posiadali klasztor w Kairze, który w roku 1189 został przejęty przez Koptów, zob. 'A. Ǧamāl ed-Dīn, Tārīh Mișr, t. 4, cz. 1, s. 12.

${ }^{39}$ Niektórzy autorzy mylnie kojarzą tę nazwę z Meliteną (Matalya w Turcji).

${ }^{40}$ N. Pigulewska, Kultura Syryjska, s. 174, 261. O napisanej przez Zachariasza kronice zob. A. Abūnā, Adab al-lug̉a, s. 232-233, a całokształt jego twórczości i jej przekłady na języki europejskie opisuje Ig̉nāțiyyos Afrem I Barșaum, Al-Lu'lu' al-manțūr, s. 254-255; Geschichte, s. 226, podając, że niektóre dzieła zachowały się tylko w syryjskim tłumaczeniu.

${ }^{41}$ Tel Mauzalt (gr. Goranopolis, tur. Viranşehr) - miasto oddalone o $10 \mathrm{~km} \mathrm{na}$ wschód od Edessy, miejsce urodzin w r. 500 J. Baradeusza. W wyniku masakr 1895 roku z 7 tys. chrześcijan pozostało przy życiu 600 Ormian i 480 Asyryjczyków, a w roku 1915 wszyscy zostali wymordowani. 
sze dane zawiera manuskrypt kaligrafowany w roku 703: „Podstawową księgą była Hexapla Orygenesa, którą na prośbę patriarchy Atanazego $(† 631)$ i w czasie służby przeora Teodoresa ${ }^{42}$ przełożył w lutym 616 roku w klasztorze Antonidów (od św. Antoniego) w pobliżu wsi Anaton nieopodal Aleksandrii ${ }^{43}$.

Swój pobyt w Aleksandrii wraz z grupą duchownych zaznaczył Tūmā Ḥarqelōyō (z Ḥarqel), biskup Mabug (†627?). „Z jego imieniem związane jest opracowanie zestawienia tekstów Ewangelii do czytania w święta podczas jutrzni. Od roku 616 zajmował się w klasztorze Antonidów tłumaczeniem Nowego Testamentu z greki na syro-mezopotamski, które to tłumaczenie zyskało dużą popularność i przez długi czas było używane w liturgii w SKOA"44.

Do osób świeckich, które odcisnęły swoje piętno w historii nauki i kultury arabskiej i któremu Europa wiele zawdzięcza, jest Hunayn ibn Isḥāq, „nestorianin” (zm. 873). Urodzony w Al-Hīra przeniósł się do Bagdadu, gdzie uczył się u słynnego Yuhannā Māsawyeh, następnie udał się do Aleksandrii. Po perfekcyjnym opanowaniu języka greckiego i wyposażeniu w rękopisy w tym języku powrócił do Bagdadu i zaczął tłumaczyć dzieła Hellady na syro-mezopotamski, a następnie na arabski bądź bezpośrednio na arabski. Jest autorem dziesiątków prac, w tym leksykalnych, szczególnie z dziedziny medycyny ${ }^{45}$.

${ }^{42}$ Tę postać opisuje E. Scholastyk, Historia Kościoła, op. cit., indeks nazw osobowych.

43 Ig̉nāțiyyos Afrem I Barșaum, Al-Lu'lu' al-manțūr, s. 272-274; Geschichte, s. 241-243; A. Abūnā, Adab al-lug̀a, s. 239.

${ }^{44}$ N. Pigulewska, Kultura Syryjska, s. 262. Egzemplarz tego tłumaczenia znajduje się w bibliotece augustyniańskiej w Rzymie, a w nim: „Cztery Ewangelie przełożono skrupulatnie z greki na syryjski w czasach Filoksenosa, biskupa Mabug. Ja, Tūmā, zestawiłem i porównałem to tłumaczenie z trzema egzemplarzami greckimi, które znajdują się w klasztorze Antonidów w Wielkiej Aleksandrii w roku 616”. Zob. też Mār Mihoōyel Rābō, Kronika, s. 270; Geschichte, s. 244-245.

45 Encyclopedia Britannica (https://www.britannica.com/biography/Hunayn-ibn-Ishaq dostęp: 20.07.2018); J. Bielawski (red.), Mały słownik kultury świata arabskiego, Warszawa 1971, s. 194-195; A. M. 'A. ad-Dabiān, Hunayn ibn Isḥ̄ā - dirāsa tārīḥiyya wa lugawiyya, Rijad 1993, t. 1. ss. 323, t. 2, ss. 393. Szczególne cenna jest długa lista stworzonych przez Ḥunayna neologizmów arabskich na bazie syryjskiego, zajmująca część pierwszego tomu i cały drugi tom. 


\section{DWA ZJEDNOCZONE PATRIARCHATY}

Po Soborze Chalcedońskim nowo wybrani patriarchowie obu stolic zwykli wymieniać między sobą tzw. synodikon, tj. afirmacja wiary ojców przeciwko herezjom i deklaracja potwierdzająca trwanie $\mathrm{w}$ jedności. Tak np. postąpił antiocheński Atanasiyyos (Atanazy) I (595-631), który po wyborze Anestaza na papieża Aleksandrii (603-614) wybrał się do niego z pięcioma biskupami i wieloma mnichami, wożąc dary. Koptyjski papież wyszedł im na spotkanie wraz z duchowieństwem i tłumem wiernych. Wszyscy śpiewali pieśni kościelne. Po ceremonii patriarchowie razem odprawili mszę świętą, jeden przyjął komunię z rąk drugiego, po czym Atanazy wygłosił kazanie. Antiocheńska delegacja była ugoszczona w Egipcie przez 40 dni. A po zaśnięciu Anestaza, jego następca, Andronikos, wysłał do Atanazego synodikon. Tak też było, kiedy na tronie patriarszym Antiochii zasiadł Ēliyyā (Eliasz) I (†723). Oddelegował on biskupa Sțefanosa z listem do papieża Aleksandrii Iskandar II (†726), który „ucieszył się i odwzajemnił się podobnym listem” ${ }^{46}$.

To, co dobitnie świadczy o jedności między oboma Kościołami, jest praktykowane przez skrybów datowanie ksiąg. W wielu księgach umieszczone są w kolofonach informacje typu: „kaligrafowano za pontyfikatu patriarchów antiocheńskiego i koptyjskiego", z podaniem ich imion.

Po objęciu tronu patriarszego w Antiochii przez Dionosiyyosa (Dionizy) z Tel Mahre (817-845) ${ }^{47}$ doszło w roku 825 ze strony muzułmańskiego zarządcy Edessy, Muḥammada, brata emira Egiptu 'Abdullāha ibn Ṭāhira, do aktów agresji wymierzonych w chrześcijan: tenże Muḥammad

${ }^{46}$ M. Yūḥannā, Tārīḥ al-kanīsa, s. 315. 'A. Ğamāl ed-Dīn we wprowadzeniu do książki S. ibn al-Moqaffa' podaje, że wszystkie listy do roku 1078 zebrano i wydano w Egipcie pod tytułem „Wyznania Ojców”, Tārīh Miṣr, t. 1, s. 10. Treści kilku listów od Sewera do Teodozjusza i od Teodozjusza do Sewera przytacza Mār Mihōyel Rābō, Kronika, t. 2, s. 94-120. Warto też wspomnieć o czterdziestu jeden listach i sześciu mowach skierowanych do koptyjskich duchownych przez niebędącego patriarchą św. Jakuba z Sarug. Swoje pisma wysyłał w jednym egzemplarzu do zamieszkałego w Sketis Asyryjczyka Y. Darāwā, ten zaś przepisywał je i przekazywał adresatom.

${ }^{47}$ Patriarcha jest autorem m.in. kroniki, którą wydano po łacinie, francuskim i angielskim. Poddał ją analizie źródłowej i opracował W. Witakowski, The Syriac Chronicle of Pseudo-Dionysius of Tel-Mahree. A Study in the History of Historiography, Uppsala 1987. 
kazał zniszczyć lub zamienić na meczety wszystkie klasztory i kościoły Edessy. Biskupem miasta był wówczas Teodozjusz ${ }^{48}$, brat patriarchy Dionosiyyosa. Skala dewastacji zaniepokoiła patriarchę, toteż postanowił wybrać się do Egiptu wraz ze swoim bratem, aby starać się zatrzymać falę barbarzyństwa. Źródła podają, że kiedy patriarcha dotarł do Egiptu wyszło na jego spotkanie blisko 30 tysięcy wiernych z papieżem Aleksandrii Jakubem (819-830) na czele, chóralnie powtarzając: „Ziemia Egiptu wita przybyłego do niej czwartego z kolei patriarchę Antiochii, zastępcę św. Piotra i orędownika pokoju”.

Nazajutrz goście złożyli wizytę 'Abdullāhowi ibn Ṭāhirowi. Po wyłożeniu celu przybycia, tenże podobno miał oznajmić: „Wystarczyłoby, aby biskup Edessy wysłał list w tej sprawie, a nie pofatygować także patriarchę męczącą podróżą. Na taki list odpowiedziałbym pozytywnie”. Patriarcha wyjaśnił: „Biskup Edessy przybył, by złożyć skargę na zarządzającego w waszym imieniu miastem, ja zaś reprezentuję całą swoją wspólnotę, która cierpi z tego powodu, a Edessa stanowi tylko jej część". Słysząc to, emir napisał list, w którym zobligował brata do zwrotu skonfiskowanych obiektów, odnowy zniszczonych i szanowania mienia chrześcijan. Otrzymawszy żelazny list duchowni powrócili do Edessy i odzyskali swoje świątynie ${ }^{49}$.

Sześć lat później wybuchło powstanie Koptów protestujących przeciwko coraz wyższej dżizji od „niewiernych”50. Doszło też do niepokojów wśród samych Koptów, którzy stanowili zdecydowaną większość mieszkańców Egiptu. Zaniepokojony powagą sytuacji kalif Al-Ma’mūn zwrócił się o pomoc i mediację do patriarchy Dionosiyyosa. Obaj udali się do Egiptu razem. Ówczesny papież Aleksandrii, Jusap (Józef), powitał przybyłego patriarchę i udał się z nim do miejsca największych protestów. Swoim autorytetem patriarchowie uspokoili resztkę buntujących się; okazało się,

${ }^{48} \mathrm{O}$ nim w A. Abūnā, Adab al-lugga, s. 353-354. Jest autorem kroniki obejmującej lata 753-812 i tłumaczem z greki na syryjski m.in. utwory poetyckie Grzegorza z Nazjanzu.

49 Dokładną relację o przebiegu podróży do Egiptu i rozmowach z emirem podaje Mār Mihōyel Rābō, Kronika, t. 3, s. 23-27.

${ }^{50}$ Zrywów Koptów przeciwko władzy muzułmańskiej było kilkanaście, do roku 750 nazywano je „biernym oporem”, a po tej dacie określono terminem „rewolucja” wszystkie krwawo stłumiono. 
że wojsko muzułmańskie zdążyło wyciąć w pień tysięcy Koptów. Wykorzystując swój drugi pobyt w Egipcie gość zwiedził jego zabytki, w ten sposób opisując jedną z piramid: „Jest zbudowana z wielkich trójkątnych głazów, podobnych do tych z marmuru, które są w Baalbeku. Każdy głaz ma prawie 60 łokci długości, 6 łokci szerokości i tyleż grubości. Na szczycie piramidy znajduje się kamienny cokół długości około 10 łokci, wysokość zaś całej piramidy wynosi blisko 70 łokci. Na ścianach piramidy, od góry aż do dołu, są wyrzeźbione podobizny bożków oraz jakimś pismem, którego nikt w naszych czasach nie potrafi czytać" ${ }^{51}$.

Mār Mihōyel Rābō (†1199) w swojej Kronice napisał:

Do roku 715 kronikarze syro-mezopotamscy zwykli napisać w kolofonach swoich dzieł imiona patriarchów czterech świętych stolic: Rzym, Konstantynopol, Aleksandria i Antiochia, ale po tej dacie przestali wspominać Rzym i Konstantynopol. Po opanowaniu Syrii i Egiptu przez muzułmanów zaniechali wymienianie chalcedończyków i ograniczyli się do patriarchów Egiptu i Syrii, ponieważ nasz asyryjski lud żyje w obu krajach ${ }^{52}$.

Tę historycznie ważną notatkę potwierdza lista wymienionych przez niego patriarchów aleksandryjskich z epizodami z życia niektórych z nich. Nie mniej ważna jest informacja, że dopiero od połowy XII wieku, za pontyfikatu 70. papieża Aleksandrii Gabriela II (1131-1145), język arabski stał się językiem powszechnym w Egipcie. W związku z tym tenże patriarcha zajął się tłumaczeniem z koptyjskiego na arabski Starego i Nowego Testamentu oraz ksiąg liturgicznych, zobowiązując kler do czytania przewidzianych podczas nabożeństwa fragmentów najpierw $\mathrm{w}$ arabskim, a potem w koptyjskim. Kiedy tron aleksandryjski objął Joannis V (1147-1166) oddelegował on posłańca do patriarchy Antiochii Mār Mihōyel Rābō z listem napisanym po raz pierwszy w obu językach ${ }^{53}$.

${ }^{51}$ Dziękuję profesorowi Hieronimowi Kaczmarkowi za weryfikację błędnie podanej w źródłach asyryjskich nazwy tej piramidy, twierdząc, że opis odpowiada piramidzie Cheopsa w Gizie. O misji patriarchy i jego twórczości piszą A. S. Atiya, Historia Kościołów, s. 172; Ibn al-'Ibrī (Bār'Ebrāyā), Tārīh az-zamān, Bejrut 1986 (w arabskim tłumaczeniu I. Armala), s. 28-31 (w nim także o wizycie w Bagdadzie w r. 836 Gorgiego, króla chrześcijańskiej wówczas Nubii).

${ }^{52}$ Mār Mih̄ōyel Rābō, Kronika, t. 2, s. 378; t. 3, s. 45-48.

${ }^{53}$ Mār Mih̄ōyel Rābō, Kronika, t. 3, s. 207, 378. Imię papieża Aleksandrii wy- 
Warto zaznaczyć, że do połowy XIII wieku sprawy Kościoła Koptyjskiego w Ziemi Świętej reprezentował Kościół Antiocheński. Zgodnie z porozumieniem papież Aleksandrii Korillos (Cyryl) III (1235-1243) wyznaczył biskupa Bāseliyyosa (Bazylego) do sprawowania opieki nad gminą koptyjską i koptyjskimi posiadłościami w Ziemi Świętej, a patriarcha Antiochii wyznaczył biskupa imieniem Tūmā dla gminy asyryjskiej w Abisynie, którą dotychczas opiekał się Kościół Aleksandrii ${ }^{54}$.

Źródła kościelne podają, że „po odejściu ${ }^{55}$ patriarchy antiocheńskiego Filoksenosa, ze względu na niemożność powołania synodu, kler poprosił biskupa Šemūuna Ṭuŕabdinōyō, aby postarał się przedostać do Egiptu i tam zostać konsekrowany na patriarchę. Konsekracji przy udziale zaproszonego asyryjskiego biskupa Jerozolimy Korillosa, zwanego Bār Nišānem, dokonał koptyjski papież Gabriel V (†1428). Nowy patriarcha przyjął imię Bāseliyyos IV Šemūn. Trwające niepokoje w Syrii i Mezopotamii nie pozwoliły nowemu patriarsze wrócić. Udał się do Jerozolimy i tam zmarł w r. 1444. Po wyborze Juannisa XI na papieża Koptów, do Aleksandrii wybrał się syryjski patriarcha İgnāțiyyos Behnām I Ḥadalōyō (†1545), następca Bāseliyyosa IV Šemūna, aby złożyć mu życzenia. Podczas pobytu w Egipcie razem z papieżem aleksandryjskim odprawił w Niedzielę Palmową nabożeństwo w kościele Dziewicy Marii, zwanym „al-mu'allaqa” (zawieszony), a w Wielki Czwartek poświęcił olej (myron,

stępuje w brzmieniu Iwannis, a list dostarczył oddelegowany przez niego biskup Piotr Starzec.

${ }^{54}$ I. H.. Al-Mișrī, Qișșat al-kanī̄sa al-mișriyya (brak miejsca wydania) 2003, wyd. VIII, t. 3, s. 186-188. Autorka pisze też o wymianie listów i poselstw między papieżem Aleksandrii a patriarchą Antiochii w związku z tymi uzgodnieniami. Siedzibę biskupa koptyjskiego stanowiła nie Jerozolima, lecz Gaza. Gaza była silnym ośrodkiem chrześcijańskim z wyższą szkołą. Po arabskim podboju jej wykładowcy uciekli do Gruzji, gdzie znajduje się dziś klasztor pod wezwaniem Trzynastu Oświecicieli Asyryjskich ze znanym chórem prowadzonym przez o. Serafima Bit-Kharibi, http://misyjne.pl/kim-wlasciwie-jest-o-serafim-bit-haribi-wideo/ (dostęp 20.07.2018).

${ }^{55}$ W przypadku duchownych w Kościołach asyryjskich nie używa się czasowni-

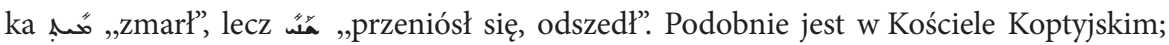
użyty tutaj arabski czasownik نَيَّ tanayyạ, będący zarabizowaną formą syryjskiego czasownika in iltnīh, oznacza „odpoczął [w Bogu]”. 
krzyżmo), który gość zabrał dla swoich świątyń ${ }^{56}$. Ostatni patriarcha antiocheński, który odwiedził znajdujące się w Egipcie diecezje syro-mezopotamskie był Ig̉nāṭiyyos Yuhannā XIII (†1493). To jednak nie oznacza, że kontakty zostały zerwane. Jeszcze w osiemnastym wieku Asyryjczycy w Egipcie stanowili niemałą społeczność; pierwsza drukarnia w Egipcie, którą sprowadził Napoleon (1798 r.) była wyposażona w czcionki syryjskie, a zarządzenia cesarza drukowano także w tym języku. Pomimo że większość członków Kościołów syro-mezopotamskich rozproszyła się w Egipcie; część przystąpiła do Kościoła Koptyjskiego, a część w wyniku działalności misjonarzy zatraciła swoją tożsamość, relacje oparte na nauce pierwszych ojców Kościoła trwają nieustannie do dziś. Obecnie ta społeczność liczy zaledwie kilkaset osób, z dominującą grupą unicką.

\section{KONKLUZJA}

Źródła syro-mezopotamskie wymieniają nazwy egipskich miejscowości, które mają asyryjskie pochodzenie, podają szczegółowe informacje o licznych kościołach i klasztorach zbudowanych w Egipcie i prowadzonych przez duchownych z Syrii i Mezopotamii wraz z liczbą wiernych, sięgającą w niektórych okresach kilkuset.

Obecnie dramatyczne dla chrześcijan Bliskiego Wschodu warunki są dobrym sprawdzianem międzychrześcijańskiej solidarności. W uznaniu zasług wielkiego asyryjskiego filantropa S. Āgāăāana po katastrofalnych dla Asyryjczyków wydarzenia po inwazji amerykańskiej na Irak, papież Aleksandrii Tawadros przyznał mu wysokie odznaczenie. Tak też było w roku 2014 po opanowaniu i splądrowaniu Mosulu i Doliny Niniwy przez ISIS. Dużym pocieszeniem dla tych, którzy uszli z życiem i znaleźli się w prowizorycznych obozach w północnym Iraku, była wspólna robocza wizyta do nich patriarchów wszystkich Kościołów Bliskiego Wschodu, w tym Koptyjskiego i maronickiego. Inny dowód na chrześcijańską postawę Kościoła Aleksandrii był udział papieża Tawadrosa na ciele 50-osobowej delegacji wraz z delegacją Kościoła Etiopii w zorganizowanych w Erewanie

56 Według I. Ḥ. Al-Mișrī, Qișşat al-kanī̄sa, s. 336, 340-341 pobyt delegacji trwał kilka miesięcy, jednak autorka pomy-liła kolejność patriarchów. 
20-26 kwietnia 2015 r. obchodach setnej rocznicy holocaustu dokonanego na Ormianach przez Turków i Kurdów.

\section{BIBLIOGRAFIA}

Abūnā A., Adab al-lugia al-ārāmiyya [Literatura języka aramejskiego], Bejrut 1996.

Abūnā A., Šuhadä’ al-mašriq [Męczennicy Wschodu], t. 1, Bagdad 1985.

Armala I., As-Syriān fĩ al-qutr al-mişrì [Asyryjscy chrześcijanie w Egipcie], Bejrut 1925. Armala I., Tärīh al-kanīsa as-syriāniyya, Bejrut 1996.

Atanazy Aleksandryjski, św., Żywot świętego Antoniego. Św. Antoni Pustelnik. Pisma,

Z. Brzozowska i inni (tłum.), E. Wipszycka (wstęp i komentarz), Warszawa 1987.

Atiya A. S., Historii Kościołów Wschodnich, Warszawa 1978.

Bār'Ebrāyā, Hūdōyēe, Glane/Losser, Holandia 1986.

Bār'Ebrāyā (Ibn al-'Tbrī), Tārīh az-zamān [Historia czasów], Bejrut 1986.

Barșaum, İ̉nāțiyyos Afrem I, Al-Lu'lu' al-mantūr fì tārīh al-ưlūm wa-l-ādāb as-syriāniyya [Rozsypane perly w historii nauki i literatury syryjskiej], Bagdad 1976.

Barșaum, Ig̉nāṭiyyos Afrem I, Geschichte der syrischen Wissenschaften und Litetatur (tłumaczenie z arabskiego G. Toro i A. Gorgis), Wiesbaden 2012.

Baumer Ch., The Church of the East. An Illustrated History of Assyrian Christianity, London-New York 2008.

Bielawski J. (red.), Mały słownik kultury świata arabskiego, Warszawa 1971, s. 194-195.

Butcher E. L., History of the Coptic Nation and Orthodox Church, London 1897 (arabskie tłumaczenie: Tārīh al-umma al-qibtiyya wa kanisatihā, tłum. I. Tadarus, t. 1 i 2 , Kair 1900-1901).

Dabiān (ad-) A. bin M. bin 'A., Hunayn ibn Ishạa - dirāsa tārīhiyya wa luġawiyya [Ḥunayn ibn Isḥāq - studium historyczne i filologiczne], t. 1 i 2, Rijad 1993.

Daniélu J., Marrou H. I., Historia Kościoła, Warszawa 1984, t. 1, s. 218-219, 280.

Dāwūd K. J., Al-Lumia aš-šahiyya fì naḥū al-lug̉a as-syriāniyya [Rozkoszna luminescencja w gramatyce języka syryjskiego], t. 1, Mosul 1896.

Duval R., Tārīh al-adab as-syriānī [Historia literatury asyryjskich chrześcijan] (tłumaczenie z francuskiego L. Qașșāb), Bagdad 1992.

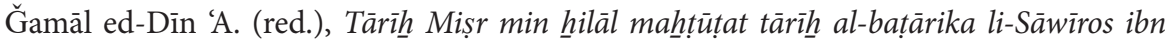
al-Moqaffa' [Dzieje Egiptu na podstawie manuskryptu „Dzieje patriarchów” Sāwīrosa ibn al-Moqaffa'], t. 1, Kair 2006.

Encyclopedia Britannica (https://www.britannica.com/biography/Hunayn-ibn-Ishaq - data dostępu: 20.07.2018).

Euzebiusz z Cezarei, Historia Kościoła. O męczennikach Palestyńskich, Poznań 1924.

Harrak A. (tłumaczenie i wprowadzenie), The Acts of Mār Māri the Apostle, Atlanta 2005. Hollerweger H., Turabdin - Living Cultural Heritage, Linz 1999.

Kāmil M., Bakrī (al-) M. H., Rušdī Z. M., Tārīh al-adab as-syriānī min našatihi ilā al'aṣr 
al-hạạir [Historia literatury syryjskiej od jej powstania do czasów współczesnych], Kair 1987.

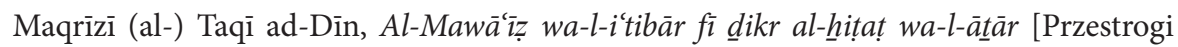
i napomnienia we wspomnieniu o okręgach i pomnikach], M. Zenhum, M. ašŠarkāwī (red.), t. 2, Kair 1998.

Mār Michōyel Rābō, Texts and Translations of the Chronicle of Michael The Great, G. A. Kiraz (ed.), vol. 1, The Edessa-Aleppo Syriac Codex of the Chronicle of Michael The Great, A Publication of St. George Parish and Edessian Community in Aleppo, Piscataway/NJ 2009.

Mār Michōyel Rābō, Tārīh Mār Mīhāàil as-syriānī al-kabīr [Kronika Michała Syryjskiego Wielkiego], t. 2 i 3, Aleppo 1996.

Mār Michōyel Rābō, Kțōbō d-makțbōnūt zabnē (b.m.w) 2006.

Miṣrī (al-) I. H., Qișṣat al-kanī̄sa al-miṣriyya, wyd. VIII, t. 3, (b.m.w.) 2003.

Pigulewska N., Kultura Syryjska we wczesnym średniowieczu, Warszawa 1989.

Schneider M., Ze źródeł pustyni. Znaczenie Ojców Pustyni dla współczesnej duchowości, Kraków 1994.

Scher A., Tārīh Kaldō wa Ātūur [Historia Chaldei i Asyrii], t. 2, Bejrut 1913.

Scholastyk S., Historia Kościoła, Warszawa 1986.

Sozomen H., Historia Kościoła, Warszawa 1989.

Riāọ Z., Kanīsat al-Iskandariyya fī Ifrīqia [Kościół Aleksandryjski w Afryce], Kair 1962.

Rustum A., Kanīsat madīnat allāh anțākiā al-uzmā [Kościół Bożego miasta, wielkiej Antiochii], t. 1, Bejrut 1988.

De Tarrazzi Ph., Aşdaq mā kān 'an tārīh Lubnān wa şafha min ah̆bār as-Syriān [Najprawdziwsze dzieje Libanu i karta z historii asyryjskich chrześcijan], t. 1, Bejrut 1948.

De Tarrazzi Ph., Așr as-Syriān ad d-dahabī [Złoty wiek chrześcijan asyryjskich], Aleppo 1979.

Thomas, Bishop of Margâ, The Book of Governors, w: Edited from Syriac Manuscripts from the British Museum and other Libraries, red. E. A. W. Budge, London1893, s. 273-281.

Tūmā Seweriyyos Ya‘qūb, Tārīh al-kanisa as-syriāniyya al-hindiyya [Historia Kościoła Syryjskiego w Indiach], Bejrut 1951.

Vööbus A., History of Asceticism in the Syrian Orient I, Louvain 1958.

Vööbus A., The Contribution of Ancient Syrian Christianity to the West European Culture, "Journal of Assyrian Academic Society", 1 (1988), s. 8-14.

Witakowski W., The Syriac Chronicle of Pseudo-Dionysius of Tel-Mahrēe. A Study in the History of Historiography, Uppsala: Acta Universitatis Upsaliensis, Studia Semitica Uppsaliensia 9, 1987.

Yáqūb III Ig̉nāṭiyyos, Naf̣ al-áaīr aw sīrat al-bațiark Mār Seweriyyos al-kabīr [Rozprzestrzenianie się wonności, czyli żywot patriarchy Mār Sewera Wielkiego], Damaszek 1970.

Yūḥannā M., Tārīh al-kanīsa al-qibtiiyya [Historia Kościoła Koptyjskiego] (b.m.w.). 